\title{
ANALISIS DAMPAK COVID-19 BAGI UMKM DI JAWA TIMUR
}

\author{
(Analysis of The Impact of Covid-19 for MSMEs in East Java)
}

\author{
Aisyah Aminy ${ }^{1}$, Kartika Fithriasari ${ }^{2}$ \\ ${ }^{1}$ Dinas Koperasi dan UKM Provinsi Jawa Timur \\ ${ }^{2}$ Institut Teknologi Sepuluh Nopember \\ Jl. Raya Bandara Juanda No.22 Siadoarjo \\ E-mail: aisyah.pns@gmail.com
}

\begin{abstract}
ABSTRAK
Pandemi covid-19 yang terjadi saat ini telah memberikan dampak terhadap berbagai sektor. Pada tataran ekonomi global, pandemi covid-19 memberikan dampak yang sangat signifikan pada perekonomian domestik dimana kondisi tersebut telah terlihat dalam pertumbuhan ekonomi Jawa Timur yang tumbuh sebesar 3,04 persen pada triwulan I jauh dari rata-rata pada periode yang sama yang berada di angka 5 persen. Kondisi tersebut juga dialami oleh usaha mikro, kecil, dan menengah (UMKM) di Jawa Timur. Melambatnya pertumbuhan ekonomi di Jawa Timur akibat covid-19 ini sangat berdampak bagi UMKM dimana pada tahun 2016 hingga 2018 UMKM telah berkontribusi lebih dari 50 persen terhadap perekonomian Jawa Timur. Oleh karena itu, diperlukan penelitian terhadap dampak covid-19 bagi UMKM di Jawa Timur sehingga dapat diambil langkah kebijakan dalam menentukan rekomendasi program pemberdayaan di masa pandemi. Metode pengambilan data dilakukan menggunakan survei secara online kepada pelaku UMKM di Jawa Timur di berbagai sektor secara nonprobabilitas sampling. Dari hasil survei didapatkan 31.183 data dimana terdapat 4 (empat) sektor utama yang terdampak yaitu industri pengolahan, penyediaan akomodasi dan makan minum, perdagangan, serta pertanian, kehutanan, dan perikanan. Selanjutnya dilakukan identifikasi permasalahan terhadap UMKM terdampak, dimana 48 persen mengalami permasalahan pada penjualan. Hal ini dikarenakan terdapat beberapa kebijakan yang diambil Pemerintah yaitu Pembatasan Sosial Skala Besar (PSBB), Work From Home (WFH), dan School From Home (SFH) sehingga menyebabkan perubahan pada mobilitas masyarakat yang ditunjukkan oleh indeks mobilitas masyarakat yang mengalami penurunan. Oleh karena itu, rekomendasi yang dapat diberikan adalah adanya pendampingan pemasaran online bagi UMKM serta kemudahan akses pembiayaan.
\end{abstract}

Kata kunci: Covid-19; UMKM; Jawa Timur.

\section{ABSTRACT}

The covid-19 pandemic that is currently happening has had an impact on various sectors. At the global economic level, the covid-19 pandemic has very significant impact on the domestic economy where this condition has been seen in the economic growth of East Java which grew by 3,04 percent in the first quarter, far from the average in the same period which was 5 percent. This condition is also experienced by micro, small and medium enterprises (MSMEs) in East Java. The slowdown in economic growth in East Java due to covid-19 has had a major impact on MSMEs, where from 2016 until 2018 MSMEs contributed more than 50 percent to the East Java economy. Therefore, research is needed on the impact of covid-19 for MESMEs in East Java so that policy steps can be taken in determining empowerment program recommendations during a pandemic. The data collection method was carried using an online survey of MSME players in East Java in various sectors by means of nonprobability sampling. From the survey results obtained 31.183 data where there are 4 (four) main sectors affected, namely the processing industry, the provision of accommodation and food and drink, trade, as well as agriculture, forestry and fisheries. Furthermore, the identification of problems with affected MSMES was carried out, where 48 percent experienced problems with sales. This is because there are several policies taken by the Government, namely Large-Scale Social Restrictions (PSBB), Work From Home (WFH), and School From Home (SFH), causing changes in community mobility as indicated by the decreasing community mobility index. Therefore, the recommendation that can be given is online marketing assistance for MSMEs and financing access facilities.

Keywords: covid-19; MSMEs, East Java.

\section{PENDAHULUAN}

Pandemi Covid-19 yang terjadi saat ini telah memberikan dampak terhadap berbagai sektor. Pada tataran ekonomi global, pandemi COVID-19 memberikan dampak yang sangat signifikan pada 
perekonomian domestik dimana kondisi tersebut telah terlihat dalam pertumbuhan ekonomi Jawa Timur yang tumbuh sebesar 3,04 persen pada triwulan I jauh dari rata-rata pada periode yang sama yang berada di angka 5,55 persen (BPS Jatim, 2020). Kondisi perekonomian pada triwulan II tahun 2020 semakin terpuruk dimana mengalami kontraksi 5,90 persen jika dibandingkan triwulan II tahun 2019. Di masa pandemic covid-19 ini, hampir semua usaha mengalami konstraksi, namun terdapat beberapa lapangan usaha yang mengalami pertumbuhan positif yaitu lapangan usaha informasi dan komunikasi, jasa kesehatan dan social serta pertanian, kehutanan dan perikanan.

Kondisi tersebut juga dialami oleh usaha mikro, kecil, dan menengah (UMKM) di Jawa Timur dimana proporsi Usaha Mikro Kecil (UKM) di Jawa Timur mendominasi aktivitas ekonomi dengan proporsi sekitar 98,95 persen (BPS Jatim, 2018). Peran UMKM di Jawa Timur ini cukup signifikan, Hasil perhitungan nilai tambah K-UMKM Jawa Timur menunjukkan bahwa pada tahun 2016 UMKM berkontribusi sebesar 56,43 persen meningkat menjadi 56,63 persen pada tahun 2017 dan pada tahun 2018 juga mengalami peningkatan menjadi 56,93 persen. Akan tetapi, dengan adanya pandemic covid-19 UMKM di Jawa Timur memaksa setiap usaha untuk memutar haluan strateginya bahkan ada beberapa yang mengalami krisis (Soetjipto, 2020).

Oleh karena itu, diperlukan penelitian terhadap dampak covid-19 bagi UMKM di Jawa Timur sehingga dapat diambil langkah kebijakan dalam menentukan rekomendasi program pemberdayaan di masa pandemi. Pemberdayaan yang dilakukan di masa pandemi membutuhkan pendekatan baru, new empowerment. Penggunaan tekonologi akan menjadi alat dalam menerapkan new empowerment pada UMKM sehingga membantu mempercepat bergeraknya roda perekonomian UMKM di Jawa Timur. Oleh karena itu, diperlukan analisis dampak covid-19 bagi UMKM di Jawa Timur.

\section{METODE}

Jenis penelitian ini adalah penelitian kuantitatif dengan metode yang digunakan adalah survei secara online kepada pelaku UMKM di Jawa Timur di berbagai sektor secara nonprobabilitas sampling. Teknik pengumpulan data yang digunakan adalah dengan melakukan pengisian kuesioner kepada 31.183 orang responden dari beberapa kategori/ sektor dengan menggunakan teknik multistage random sampling dengan basis pada kategori lapangan usaha. Dimana terdapat 16 (enam belas) kategori lapangan usaha yaitu kategori A: pertanian, kehutanan, dan perikanan; kategori B: pertambangan dan penggalian; kategori C: industri pengolahan; kategori $\mathrm{D}$ : pengadaan listrik, gas; kategori E: pengadaan air, pengelolaan sampah, limbah dan daur ulang; kategori F: konstruksi; kategori G: perdagangan besar dan eceran, reparasi mobil dan sepeda motor; kategori $\mathrm{H}$ : transportasi dan pergudangan; kategori I: penyediaan akomodasi dan makan minum; kategori J: informasi dan komunikasi; kategori K: jasa keuangan dan asuransi; kategori L: real estate; kategori M, N, O: jasa perusahaan; kategori P: jasa pendidikan; kategori Q: jasa kesehatan dan kegiatan sosial; dan kategori S: jasa lainnya. Lokasi penelitian adalah di 38 Kabupaten/ Kota se-Jawa Timur. Pengambilan data dilakukan pada Bulan April s.d Mei. Metode analisis data yang digunakan dalam penelitian ini adalah menggunakan analisis statistik deskriptif.

\section{HASIL DAN PEMBAHASAN}

Jumlah UMKM di Jawa Timur berdasarkan hasil Sensus Ekonomi tahun 2016 dan Survei pertanian antar sensus tahun 2018 adalah 9,78 juta. Dimana terdiri dari sektor pertanian sebanyak 5,16 juta $(52,8 \%)$ dan sektor nonpertanian sebesar 4,61 juta (47,2\%). Untuk sektor non pertanian, didominasi oleh lapangan usaha perdagangan besar, Reparasi dan Perawatan Mobil dan Sepeda Motor sebesar 2,068 juta UMKM (44,78\%), industri pengolahan sebesar 853,9 ribu UMKM (18,49 $\%)$, penyediaan akomodasi dan penyediaan makan minum sebesar 819.483 UMKM $(17,74 \%)$, dan 12 sektor lainnya sebesar $18,99 \%$. Secara lengkap jumlah UMKM per lapangan usaha ditunjukkan pada tabel 1. 
Tabel 1. Jumlah UMKM di Jawa Timur berdasarkan Lapangan Usaha.

\begin{tabular}{lcc}
\hline \multicolumn{1}{c}{ Lapangan Usaha } & Jumlah UMKM & Ket \\
\hline Pertanian, Kehutanan, dan Perikanan & 5.163 .979 & SUTAS 2018 \\
Pertambangan dan Penggalian & 27.169 & SE 2016 \\
Industri Pengolahan & 853.974 & SE 2016 \\
Pengadaan Listrik dan Gas & 4.443 & SE 2016 \\
Pengadaan Air, Pengelolaan Sampah, Limbah dan Daur Ulang & 17.214 & SE 2016 \\
Konstruksi & 41.748 & SE 2016 \\
Perdag Besar \& Eceran; Reparasi Mobil dan Sepeda Motor & 2.068 .040 & SE 2016 \\
Transportasi dan Pergudangan & 164.037 & SE 2016 \\
Penyediaan Akom, dan Makan Minum & 819.483 & SE 2016 \\
Informasi dan Komunikasi & 112.052 & SE 2016 \\
Jasa Keuangan dan Asuransi & 19.441 & SE 2016 \\
Real Estate & 18.838 & SE 2016 \\
Jasa Perusahaan & 66.426 & SE 2016 \\
Jasa Pendidikan & 112.411 & SE 2016 \\
Jasa Kesehatan \& Kegiatan Sos & 36.148 & SE 2016 \\
Jasa lainnya & 256.859 & SE 2016 \\
TOTAL & 9.782 .262 &
\end{tabular}

Sumber: BPS Jatim (diolah), 2018

Pendifinisian UMKM diatur menurut Undang-undang No.20 Tahun 2008 tentang UMKM, dimana yang disebut UMKM adalah sebagai berikut: (1) Usaha mikro yaitu usaha yang memiliki kekayaan paling banyak Rp.50.000.000,00 atau hasil penjualan tahunan paling banyak Rp.300.000.000,00; (2) Usaha kecil yaitu usaha yang memiliki kekayaan bersih Rp.50.000.000,00 s.d Rp.500.000.000,00 atau hasil penjualan tahunan Rp.300.000.000,00 s.d. Rp.2,5 miliar; dan (3) Usaha menengah yaitu usaha yang memiliki kekayaan bersih Rp.500.000.000,00 s.d Rp.10 miliar atau hasil penjualan tahunan Rp.2,5 miliar s.d Rp.50 miliar. Di Jawa Timur proporsi usaha mikro adalah yang terbesar yaitu sebesar 93,37 persen dari total UMKM atau sebanyak 9,13 juta usaha; usaha kecil sebanyak 579.567 usaha atau sekitar 5,92 persen, dan usaha menengah sebanyak 68.835 usaha atau sebesar 0,70 persen. Sebaran UMKM Jawa Timur berdasarkan skala usaha ditunjukkan pada Gambar 1.

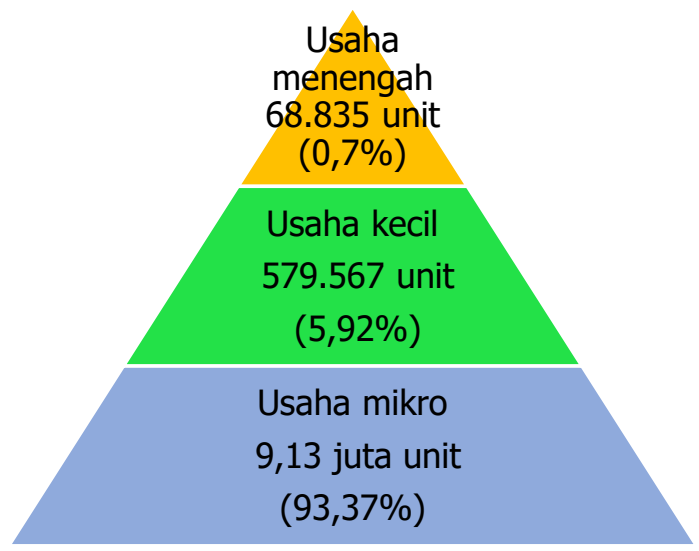

Sumber: BPS Jatim (diolah), 2018

Gambar 1. Sebaran UMKM Jawa Timur berdasarkan skala usaha. 
Hasil penelitian menunjukkan bahwa terdapat 4 sektor utama yang terdampak yaitu: (1) Industri Pengolahan sebesar 41,57 persen, (2) Penyediaan Akomodasi dan Makan Minum sebesar 23,35 persen, (3) Perdagangan Besar dan Eceran, Reparasi Mobil dan Sepeda Motor sebesar 18,6 persen, dan (4) Pertanian, Kehutanan, dan Perikanan sebesar 2,94 persen (Lia

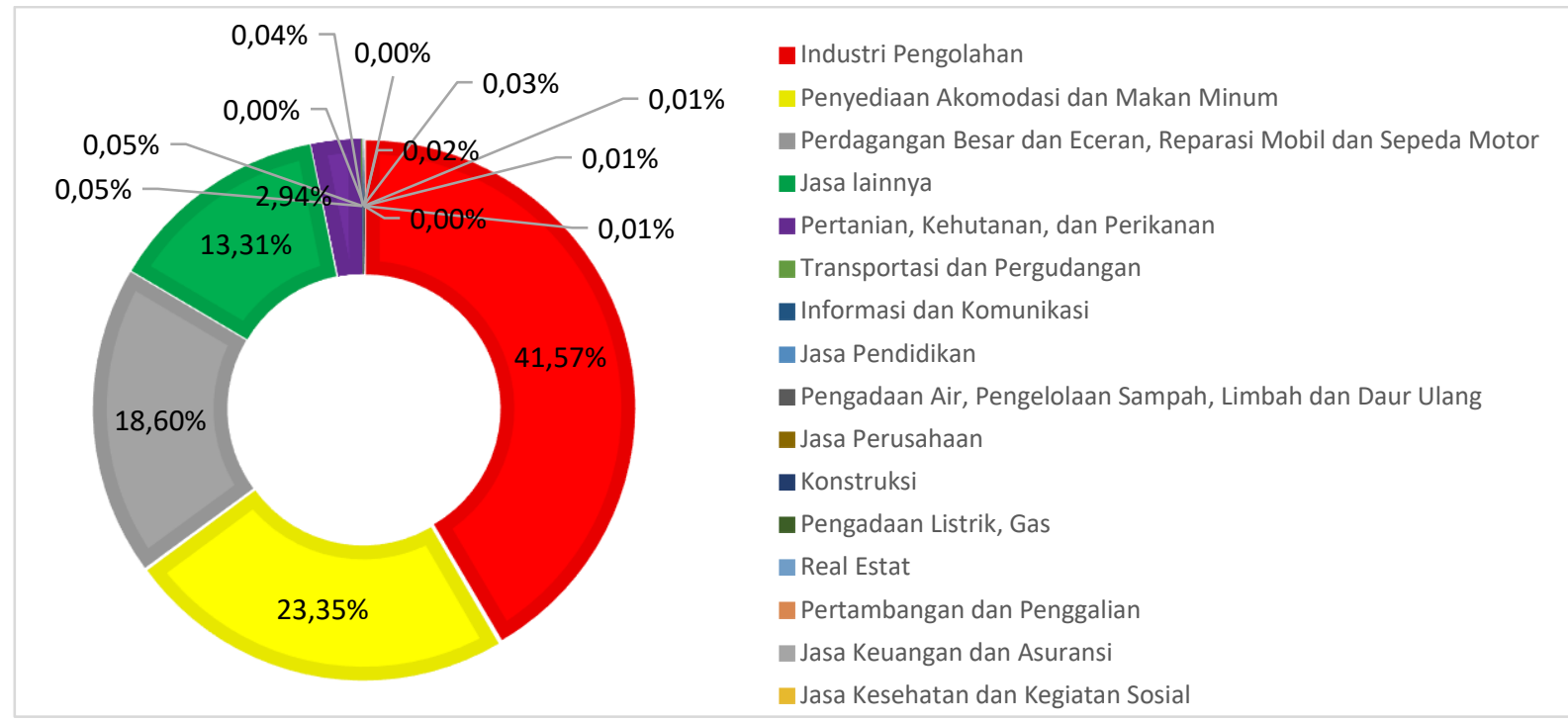

Gambar 2. Sebaran UMKM Terdampak Covid Berdasarkan Lapangan Usaha.

Dari gambar 2 diketahui bahwa industri pengolahan memiliki proporsi jumlah UMKM terdampak yang terbesar yaitu sebesar 41,57 persen. Hal ini sesuai dengan karakteristik lapangan usaha di Jawa Timur dimana struktur perekonomian Jawa Timur didominasi oleh industri pengolahan, perdagangan besar - eceran dan reparasi mobil-sepeda dan pertanian, kehutanan. Jika diperdalam lagi terhadap sektor tersebut, untuk industri pengolahan didominasi oleh olahan makanan dan minuman sebesar 97 persen dari sektor industri pengolahan, 3 persen sisanya merupakan usaha fashion, aksesoris, handycraft, dan furniture. Selanjutnya dilakukan identifikasi permasalahan terhadap UMKM terdampak tersebut, dimana hasil yang diperoleh ditunjukkan pada Gambar 3.

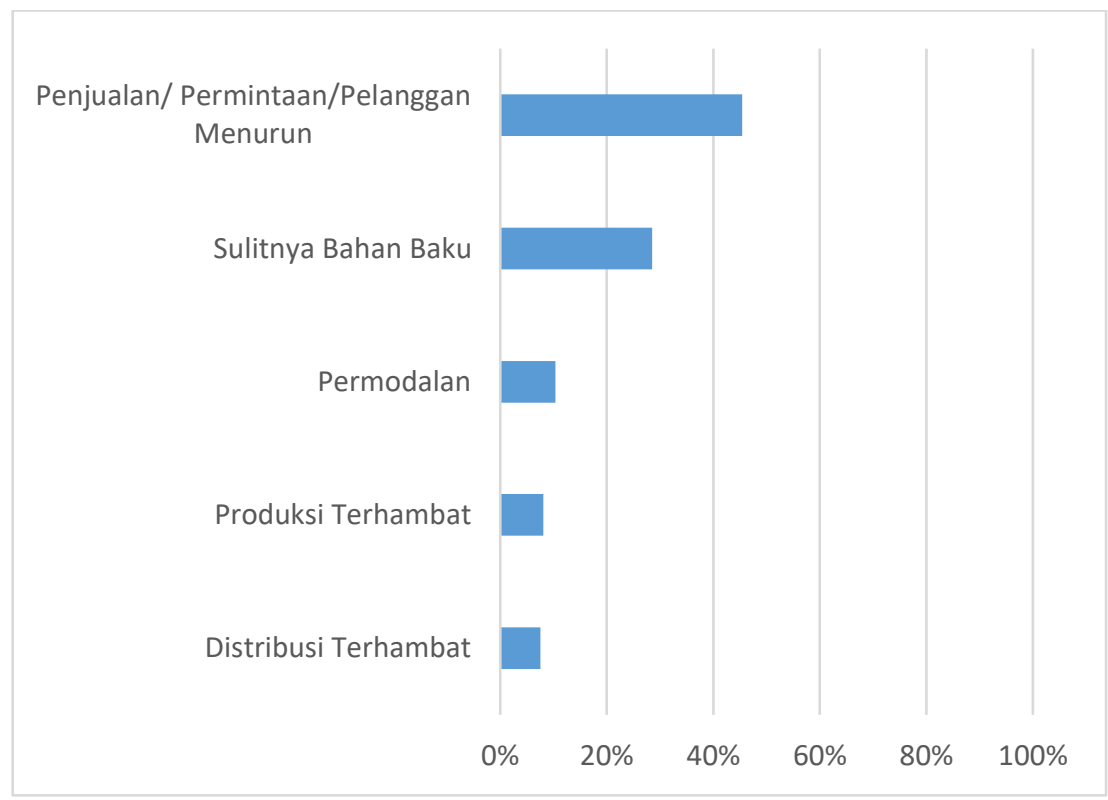

Gambar 3. Permasalahan UMKM di masa pandemic covid-19 
Dari gambar tersebut, terlihat bahwa terdapat 5 (lima) permasalahan yang dihadapi oleh UMKM yaitu sebanyak 48 persen responden mengalami penjualan menurun, 27,21 persen responden mengalami kesulitan bahan baku, 9,88 persen responden mengalami permodalan, dan dan 7,72 persen responden mengalami hambatan produksi. Permasalahan yang ada pada UMKM disebakan karena adanya beberapa kebijakan yang diambil Pemerintah yaitu Pembatasan Sosial Skala Besar (PSBB), Work From Home (WFH), School From Home (SFH) untuk menghindari resiko penularan covid-19. Hal tersebut menyebabkan perubahan pada mobilitas masyaraka dimana indeks mobilitas masyarakat mengalami penurunan seperti yang ditunjukkan pada gambar 4 .

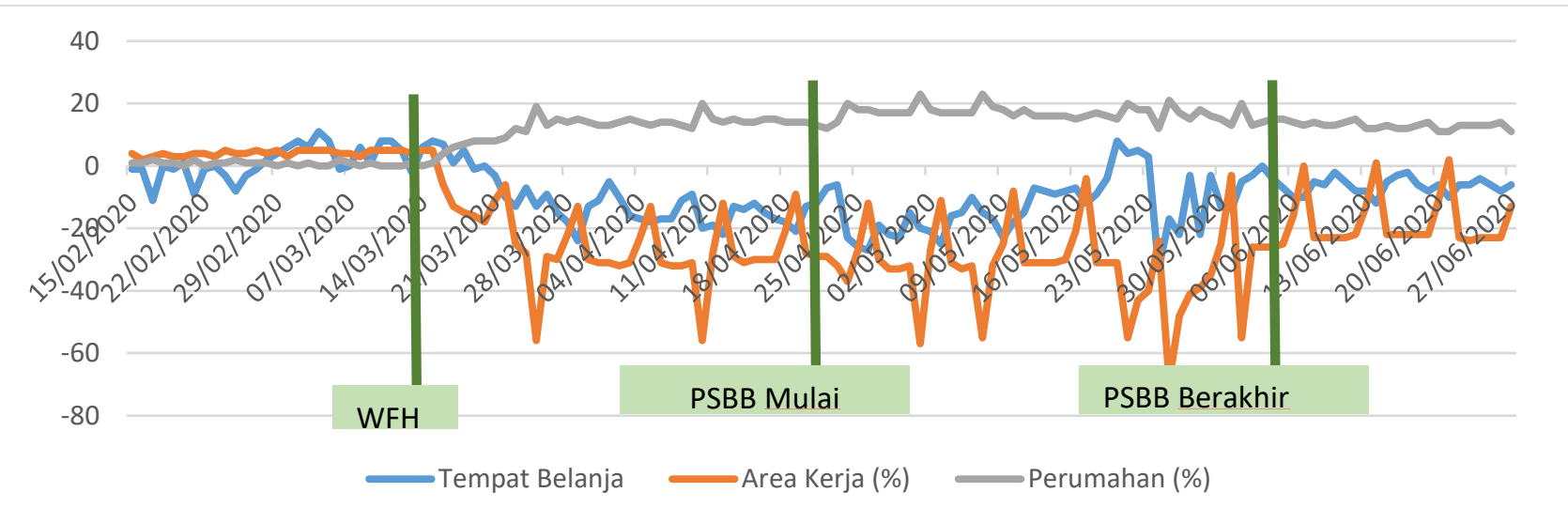

Sumber: https://www.google.com/covid19/mobility

Gambar 4. Mobilitas Masyarakat Jawa Timur (\%)

Dari gambar 4 diketahui bahwa kebijakan pembatasan sosial WFH yang dimulai 19 Maret 2020 menyebabkan adanya penurunan mobilitas masyarakat baik di tempat belanja maupun area kerja. Penurunan mobilitas masyarakat di kedua area tersebut semakin terlihat sejak adanya kebijakan PSBB yang dimulai sejak tanggal 29 April 2020 hingga 8 Juni 2020. Dampak WFH dan PSBB membuat perubahan perilaku masyarakat baik pada pola belanja seperti yang ditunjukkan pada gambar 5, maupun pola konsumsi masyarakat.

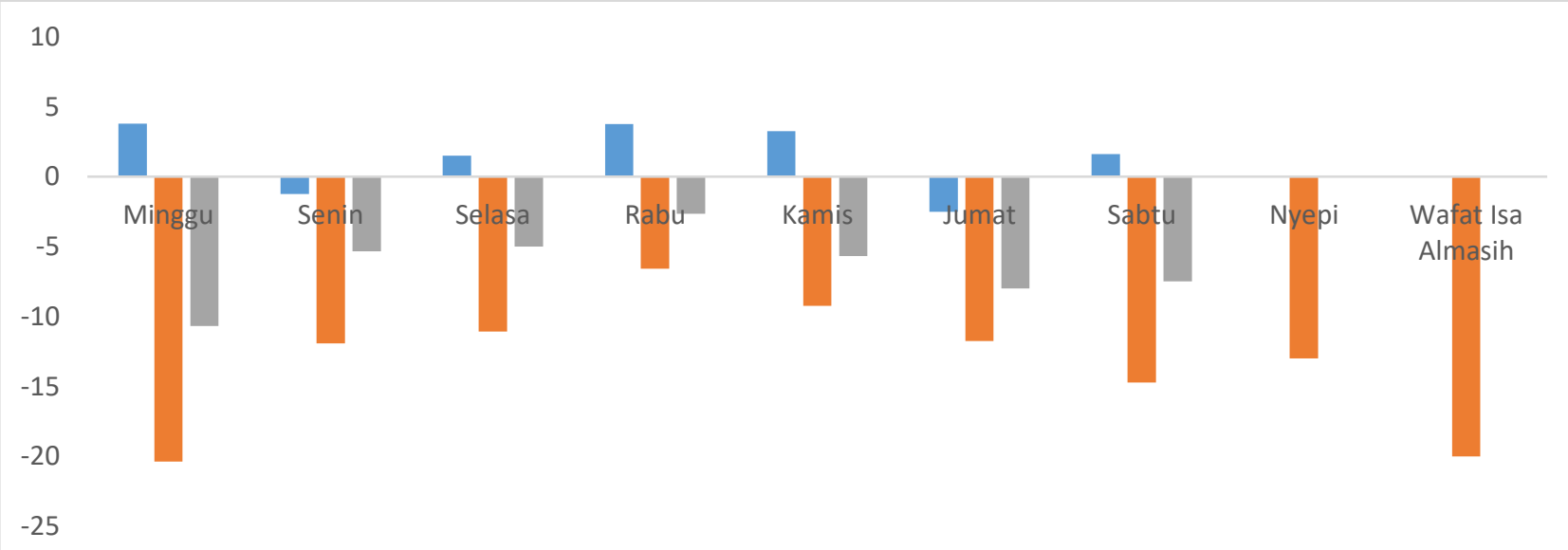

- Sebelum WFH WWFH Setelah PSBB

Gambar 5. Mobilitas Masyarakat Jawa Timur di Tempat Belanja (\%)

Gambar 5 menunjukkan bahwa pola belanja masyarakat Jawa Timur mengalami perubahan di masa pandemic covid-19 yang biasanya belanja di hari minggu berubah menjadi hari rabu. Selain itu, hasil survey sosial demografi dampak covid-19 yang dilakukan oleh BPS RI menyebutkan bahwa 31 persen responden mengalami peningkatan aktivitas belanja online selama covid-19 yaitu sebesar 42 persen, 28 persen responden mengalami penurunan sedangkan 2 persen responden sisanya 
tetap. Dari hasil survey sosial demografi dampak covid-19 yang dilakukan oleh BPS RI juga dapat diketahui bahwa terdapat perubahan pengeluaran pada komoditas belanja rumah tangga yaitu peningkatan bahan belanja bahan makanan sebagai dampak dari tren global memasak dan makan di rumah. Perubahan belanja ini sangat berdampak pada UMKM komoditas olahan makanan dimana 64 persen dari responden UMKM olahan makanan menyatakan bahwa mengalami penurunan penjualan.

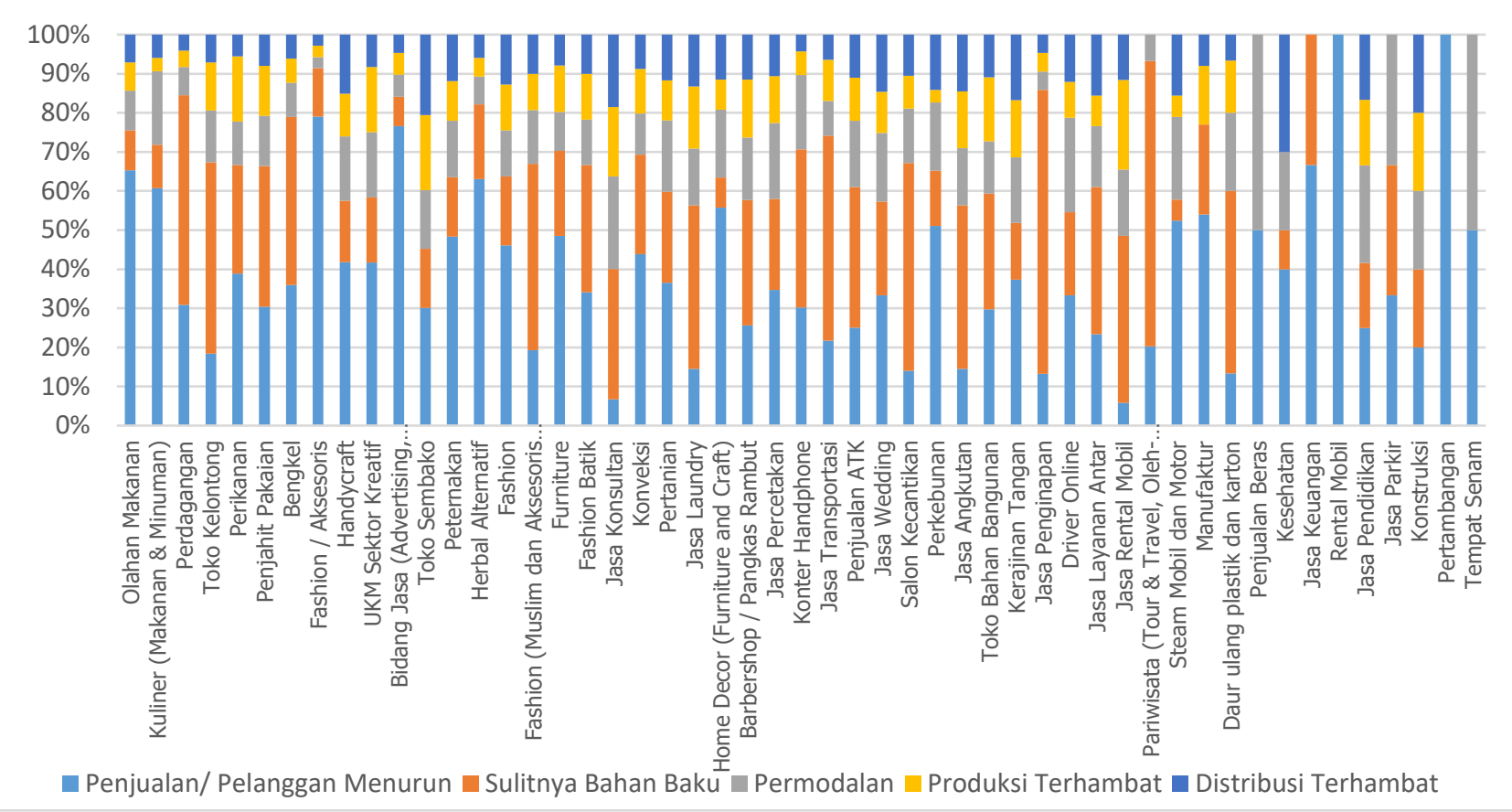

Gambar 6. Dampak Covid-19 Pada UMKM Berdasarkan Komoditas Usaha

Gambar 6 menunjukkan dampak covid-19 berdasarkan komoditas usaha dimana terlihat bahwa mayoritas mengalami penurunan penjualan dimana UMKM komoditas olahan makanan dan kuliner merupakan UMKM terdampak yang dominan dengan permasalahan terbesar pada penurunan penjualan yaitu sebesar $64 \%$ - 71\%. Selanjutnya, dilakukan analisis terhadap permintaan pasar produk UMKM dimana 89 persen produk UMKM mengalami penurunan permintaan seperti yang ditunjukkan pada gambar 7.

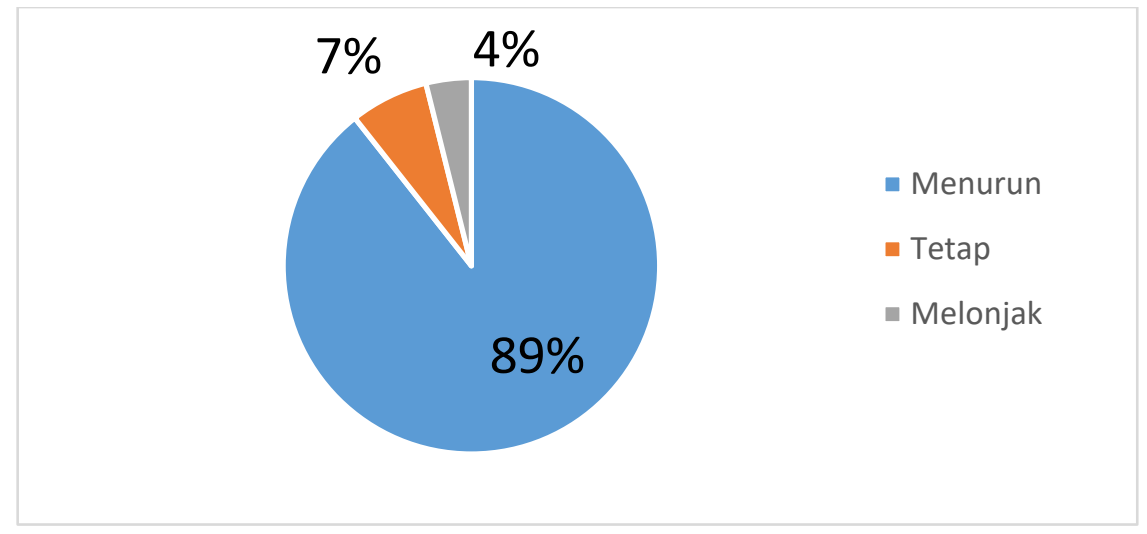

Gambar 7. Permintaan Pasar Produk UMKM Dampak Covid-19

Gambar 7 menunjukkan bahwa 89 persen produk UMKM mengalami penurunan permintaan dimana mayoritas adalah produk mamin sebesar 65 persen, fashion sebesar 12 persen, dan handycraft sebesar 9. Di sisi lain, terdapat beberapa produk yang mengalami kenaikan permintaan pasar meskipun hanya $4 \%$ yaitu produk minuman herbal sebesar 68 persen dan madu sebesar 10 persen. 
Dari analisis diatas menunjukkan bahwa pandemic covid-19 memberikan dampak negatif bagi UMKM dengan dampak terbesar pada penurunan penjualan sehingga perlu adanya perubahan perilaku pemasaran produk UMKM yaitu dengan menggunakan pemasaran digital baik pemanfaatan medsos maupun memasarkan produk melalui marketplace seperti Tokopedia, bukalapak, shopee, grabfood, dan gofood. Pemerintah telah melakukan upaya dalam mendorong UMKM untuk go digital yaitu dengan Gerakan Bangga Buatan Indonesia serta melakukan pendampingan pemasaran online hal ini karena hanya 38,7 persen UMK yang memanfaatkan internet (BPS Jatim, 2018). Permasalahan berikutnya yaitu kesulitan bahan baku dan permodalan. Oleh karena itu, perlu adanya sinergi baik antar pelaku UMKM maupun instansi pembina UMKM dalam mendampingi UMKM di masa pandemic covid untuk mencari bahan baku dan permodalan dengan bunga ringan. Pemerintah telah membuat Program Pemulihan Ekonomi Nasional untuk meringankan beban UMKM yaitu berupa insentif pajak bagi pelaku UMKM yang memiliki omset dibawah 4,8 miliar per tahun, relaksasi dan restrukturisasi kredit, serta bantuan modal usaha. Pemerintah baik Pusat maupun Pemerintah Daerah serta BUMN harus menjadi buffer dalam ekosistem usaha UMKM terutama dalam masa pemulihan ekonomi. UMKM dapat masuk dalam bela pengadaan yaitu proses pengadaan barang pemerintah khusus untuk UMKM. Selain itu, pesatnya pertumbuhan industri financial technology dapat menjadi salah satu alternatif permodalan bagi UMKM. Kehadiran fintech P2P lending, khususnya untuk menjangkau masyarakat yang tidak terjangkau pinjaman disebabkan tidak memenuhi kriteria perbankan dan perusahaan pembiayaan.

Beberapa rekomendasi yang dapat diberikan yaitu UMKM dapat memanfaatkan media sosial sebagai media pemasaran, UMKM harus fokus pada kebutuhan konsumen dengan mencari produk yang sedang diminati lewat marketplace, Selalu berinovasi dan kreatif dalam produk maupun layanan sesuai dengan perubahan perilaku konsumen, UMKM dapat mengembangkan jejaring, saling bantu usaha satu sama lain, Merencanakan ulang pendapatan dan biayan dengan melakukan efisiensi dan memanfaatkan teknologi. Permodalan fintech dapat menjadi alternatif dalam memperluas akses permodalan.

\section{KESIMPULAN}

Pandemi covid-19 telah memberikan dampak negatif bagi UMKM yaitu 48 persen responden mengalami penjualan menurun, 27,21 persen responden mengalami kesulitan bahan baku, 9,88 persen responden mengalami permodalan, dan 7,72 persen responden mengalami hambatan produksi. Sektor yang terdampak adalah industri pengolahan dengan proporsi sebesar 41,57 persen. Hal ini karena adanya kebijakan pembatasan sosial seperti WFH dan PSBB yang membuat perubahan perilaku masyarakat baik pada pola belanja maupun pola konsumsi masyarakat sehingga UMKM juga harus menyesuaikan dengan pola yang ada saat ini misalnya dengan melakukan pemasaran secara digital maupun melakukan inovasi produk sesuai permintaan pasar.

\section{DAFTAR PUSTAKA}

Aisyah, Setyowati. (2019). Riset Perhitungan Nilai Tambah K-UMKM Jawa Timur Tahun Anggaran 2019. Laporan Hasil Penelitian. Dinas Koperasi dan UKM Provinsi Jawa Timur, Sidoarjo.

BPS RI. (2018). Potensi Usaha Mikro Kecil, BPS RI, Jakarta.

BPS Jatim. (2018). Analisis Hasil SE2016 Lanjutan Potensi Peningkatan Kinerja Usaha Mikro Kecil Provinsi Jawa Timur, PT. Sinar Murni Indoprinting, Surabaya.

BPS Jatim. (2020). Berita Resmi Statistik Pertumbuhan Ekonomi Jawa Timur Triwulan I - 2020. No. 32/05/35/Th.XVIII, 5 Mei 2020.

BPS Jatim. (2020). Berita Resmi Statistik Pertumbuhan Ekonomi Jawa Timur Triwulan II - 2020. No. 52/08/35/Th.XVIII, 5 Agustus 2020.

BPS Jatim. (2020). Berita Resmi Statistik Pertumbuhan Ekonomi Jawa Timur Triwulan II - 2020. No. 52/08/35/Th.XVIII, 5 Agustus 2020.

BPS RI. (2020). Hasil Survei Sosial Demografi Dampak Covid-19. BPS RI.

Google. (2020). Laporan Mobilitas Masyarakat Selama Pandemi Covid-19. Halaman 8. https://www.google.com/covid19/mobility. [26 Juni 2020]

Pakpahan, Aknolt Kristian. (2020). Covid-19 dan Implikasi Bagi Usaha Mikro, Kecil, dan Menengah. Jurnal IImiah Hubungan International: Edisi Khusus Universitas Katolik Parahyangan, 59 - 64. 
RI (Republik Indonesia). (2012). Undang-Undang No. 20 Tahun 2008 tentang Usaha Mikro, Kecil, dan Menengah. Lembaran Negara RI Tahun 2008, No. 93. Sekretariat Negara. Jakarta.

Soetjipto, Noer. (2020). Ketahanan UMKM Jawa Timur Melintasi Pandemi Covid-19. Penerbit K-Media, Yogyakarta. 